\title{
Die NG Kerk en die oorgang na 'n nuwe Suid-Afrika
}

D E de Villiers

(UP)

\section{ABSTRACT}

\section{The Dutch Reformed Church and the transition to a new South Africa}

The comprehensive transformation of the South African society that followed the transfer of political power to a new government in 1994 has had significant consequences for the Dutch Reformed Church (DRC) and its members. In the article an analysis is given of these consequences. Attention is also given to the reaction of members of the DRC to the transformation of the society. An attempt is made to formulate a responsible approach to the new South Africa by the DRC and his members. The need for the DRC to inspire his members to be true to their Christian calling, to equip them to serve effectively and to find new and effective ways to witness publicly in the new South Africa, is stressed.

\section{INLEIDING}

Die verkiesing van 27 April 1994 het 'n nuwe staatkundige bedeling in Suid-Afrika ingelei. Wat sedertdien duidelik geword het, is dat dit om veel meer as die oorgang na 'n nuwe staatkundige bedeling gaan. Ons het die afgelope jare omvattende en radikale verskuiwinge in ons samelewing beleef wat min lewensterreine onaangetas geraak het. Ingrypende veranderinge het in die politiek, maar ook in die ekonomie en burgerlike samelewing plaasgevind. Wat ons die afgelope jare beleef het en nog steeds beleef, is niks minder as die oorgang na 'n nuwe Suid-Afrika nie.

Ook die NG Kerk en sy lidmate word diepgaande deur die oorgang na 'n nuwe Suid-Afrika geraak. In hierdie artikel word hierdie oorgang, die gevolge wat dit vir die NG Kerk inhou en die uitwerking wat dit op lidmate het, in oënskou geneem. Die vraag word ook aan die orde gestel: "Hoe behoort die NG Kerk en sy lidmate die oorgang na 'n nuwe SuidAfrika te hanteer?" 
Die oorgang na 'n nuwe Suid-Afrika word deur die volgende ingrypende verskuiwinge gekenmerk:

\section{1 'n Omvattende transformasie van die samelewing}

Hierdie transformasie het in die eerste plek op die politiek betrekking. In 1994 is die politieke mag van die Nasionale Party-regering wat slegs 'n minderheid van die bevolking verteenwoordig het, oorgedra na 'n ANCbeheerde regering wat die meerderheid van die bevolking verteenwoordig. Wat dié oordrag van politieke mag so ingrypend maak, is dat dit die eerste keer in die geskiedenis van Suid-Afrika is dat swartmense, wat die meerderheid van die bevolking uitmaak, 'n beherende aandeel in die sentrale regering van die land kry. In die sentrale regerings van vroeër het die politieke mag in die hande van blankes gelê. Hierdie regerings was geneig om voorrang te verleen aan die bevordering en beskerming van blankes se belange. Een van die gevolge was grootskaalse ongelykheid in die inkomste en welvaart van blankes en swartes. ' $n$ Ander gevolg was dat die samelewing in Suid-Afrika grotendeels ooreenkomstig die voorkeure en die waardes van die Westers georiënteerde minderheid ingerig is.

Vanweë die verlede was dit onvermydelik dat die oordrag van politieke mag in 1994 'n omvattende transformasieproses in Suid-Afrika sou inlei wat alle terreine van die samelewing sou raak: die ekonomie, onderwys, welsynsdienste, gesondheidsdienste, veiligheidsmagte, sport en die georganiseerde godsdiens. In die "Witskrif oor Heropbou en Ontwikkeling" (HOP) van September 1994 het die nuwe regering sy visie vir 'n fundamentele transformasie van Suid-Afrika uiteengesit. Die HOP as 'n geïntegreerde, samehangende sosio-ekonomiese beleidsraamwerk moes daarna strewe om al die mense van ons land te mobiliseer om die gevolge van apartheid finaal uit te wis en ' $n$ demokratiese, nie-rassige en nieseksistiese toekoms te bou'.

\subsection{Die invoering van 'n nie-rassige, liberale demokrasie}

Een van die resultate van onderhandelinge was die aanvaarding van 'n interim-grondwet wat die rasgebaseerde driekamer-stelsel van die vorige bedeling met ' $n$ volwaardige, nie-rassige, liberale demokrasie vervang het. Die interim-grondwet, asook die nuwe grondwet wat in 1996 aanvaar is, verleen aan alle volwasse inwoners van Suid-Afrika burgerregte en maak voorsiening vir 'n meerderheidsregering. Terselfdertyd word die regte van individue en godsdienstige en kulturele groepe deur 'n handves van menseregte beskerm. 
Deur die aanvaarding van 'n liberale grondwet en die invoering van 'n liberale demokrasie het die politieke liberalisme die dominante politieke ideologie in Suid-Afrika geword2. Kerke behoort hiervan deeglik kennis te neem, onder andere omdat die politieke liberalisme sterk klem lê op die regte van die individu, godsdiensvryheid en 'n duidelike skeiding van die terreine van kerk en staat. Die politieke liberalisme wat in die grondwet neerslag gevind het, is egter ' $n$ gematigde een, aangesien die regte van die individu en die regte van kulturele en godsdienstige groepe in ewewig met mekaar gebring word en godsdienstige instellinge wel toegelaat word om in staatsinstellinge 'n rol te speel.

\subsection{Die instelling van meganismes om die onreg van die verlede reg te} stel en versoening in die samelewing te bewerkstellig

Die ontwrigtende uitwerking wat die toepassing van die apartheidsbeleid, asook die dekadelange militêre stryd tussen die bevrydingsbewegings en die vorige regering gehad het, het die instelling van meganismes om die slegte erfenis van die verlede te hanteer en sover moontlik reg te stel, onvermydelik gemaak. Die instelling van hierdie meganismes het beriggewing oor die afgelope vier jaar oorheers en in 'n belangrike mate die klimaat in die samelewing bepaal.

Die Waarheids- en Versoeningskommissie (WVK) is ingestel om ernstige menseregteskendinge van die verlede te hanteer en versoening in die samelewing te bevorder ${ }^{3}$. Wetgewing wat grondhervorming reël, is aanvaar om die onregmatige vervreemding van swartmense se grond deur vorige regerings reg te stel. In die staatsdiens is 'n regstellende aksieprogram geloods om die wanbalans wat daar in die samestelling van die personeel bestaan het, uit die weg te ruim. Druk is ook op private ondernemings uitgeoefen om op bestuursvlak meer swartmense aan te stel. In die onderwys is 'n omvattende transformasieproses op gang gebring om die benadeling van swart leerlinge en studente aan bande te lê.

\subsection{Die verdieping van die morele krisis in die samelewing}

Dat ons samelewing hom in 'n ernstige morele krisis bevind, het oor die afgelope jare steeds duideliker geword. Witboordjiemisdade soos bedrog en korrupsie kom steeds meer voor ${ }^{4}$. Opvallend was ook die toename in geweldsmisdaad: moorde, aanrandings, skakings, gewapende roof en verkragting. Hierdie misdade het wye nuusdekking geniet en het ongetwyfeld 'n negatiewe uitwerking op die gewone burger se veiligheidsgevoel gehad. Dit het egter ook die toerismebedryf ernstig gestrem.

Die morele krisis kan waarskynlik aan 'n samespel van faktore uit die verlede en in die hede toegeskryf word. Die ontwrigting van die 
gesinslewe deur die trekarbeiderstelsel, die kultuur van geweld wat in swart woonbuurtes ontwikkel het in die stryd teen die vorige regering, die morele afstomping by deelnemers aan die stryd wat terwille van 'n "groter saak" bereid was om morele grense te oorskrei deur te moor en te martel, is almal faktore uit die verlede wat tot die krisis bydra. Die algemene onsekerheid wat gepaard gaan met 'n oorgangstyd, die feit dat werkloosheid sedert 1994 eerder toe- as afgeneem het, ' $n$ mentaliteit van vat wat jy kan, terwyl daar nog iets is om te vat, die vrye beskikbaarheid van wapens en die groeiende invloed van misdaadsindikate is weer faktore in die huidige samelewing wat tot die morele krisis bydra.

\section{GEVOLGE VIR DIE NED GEREF KERK}

\subsection{Modernisering en sekularisasie oefen 'n groter invloed uit}

Nie al die ingrypende veranderinge wat die afgelope aantal jare in die SuidAfrikaanse samelewing plaasgevind het, kan direk toegeskryf word aan die oordrag van politieke mag nie. Van hierdie veranderinge kan eerder toegeskryf word aan wêreldwye tendense wat ook in Suid-Afrika neerslag vind. Dit is egter wel waar dat die nuwe politieke bedeling daartoe bygedra het dat hierdie wêreldwye tendense nou groter invloed in Suid-Afrika uitoefen as voorheen. Een so 'n tendens is modernisering.

Modernisering kan omskryf word as die sosiale ontwikkeling wat gekenmerk word deur die strewe om probleme uitsluitlik met behulp van die rede op te $\operatorname{los}^{5}$. Dié ontwikkeling het sedert die Verligting groot invloed in veral Westerse lande uitgeoefen. Dit het daartoe gelei dat daar toenemend afstand tussen die kerk en ander lewensterreine soos die ekonomie en die politiek gekom het. Die historiese proses waarin ander lewensterreine hulle van die gesag en die beheer van die kerk losgemaak het, word gewoonlik aangedui as die proses van sekularisasie.

Die inperking van die invloed van die kerk op ander lewensterreine het gepaard gegaan met 'n toenemende (en omgekeerde) bem̈vloeding van die kerk en sy lidmate deur moderniseringsontwikkelinge op die ander lewensterreine. By uitstek die vryemarkekonomie met sy aanwakkering van kompetisie, verbruik en materiële besit het daartoe bygedra dat by lidmate waardes gevestig is wat moeilik met tradisioneel Christelike waardes gerym kan word.

Alhoewel die proses van sekularisasie en die bem̈loeding van lidmate deur moderniseringsontwikkelinge reeds lankal in Suid-Afrika werksaam is, het die politieke isolasie van ons samelewing, asook die groot openbare invloed van die Afrikaanse kerke, 'n remmende invloed daarop 
gehad. Met die intrede van die nuwe bedeling het hierdie remmende uitwerking egter grotendeels weggeval. Die nuwe grondwet maak dit trouens onmoontlik vir enige kerk om dieselfde invloedryke en bevoorregte rol in die openbare lewe te speel as die Afrikaanse kerke in die vorige bedeling. Een van die gevolge is dat die sekularisasieproses, die losmaking van die openbare lewe van die invloed van die kerk, nou met versnelde pas in Suid-Afrika voortgaan. ' $n$ Ander gevolg is dat lidmate van SuidAfrikaanse kerke nou meer as voorheen blootgestel word aan waardes wat spruit uit die moderniseringsproses.

\subsection{Die openbare invloed van die NG Kerk neem af}

Die NG Kerk het voor die nuwe politieke bedeling 'n invloed op die samelewing uitgeoefen wat buite verhouding tot sy lidmaattal was. Dié invloed het egter na die oorgang na die nuwe bedeling beduidend afgeneem. Die volgende faktore het onder andere daartoe bygedra:

* Die NG Kerk het nie meer soos in die vorige bedeling die simpatieke oor van regeringsleiers waarvan die meerderheid sy lidmate is nie.

* Weens die aanvaarding van 'n grondwet wat 'n groter afstand tussen kerk en staat plaas, is dit nie meer moontlik vir die NG Kerk om soos voorheen direk 'n stempel op openbare sedelikheidswetgewing af te druk nie.

* Die verteenwoordiging van die NG Kerk onder kapelane van die veiligheidsdienste en aanbieders van godsdiensprogramme op die radio en televisie neem af.

* Die sosiale voordeel wat lidmaatskap van die NG Kerk vroeër ingehou het, het sterk afgeneem.

* Weens die assosiasie van die NG Kerk met die apartheidsbeleid het hy 'n negatiewe openbare beeld.

Dit is nodig om by te voeg dat nie net die NG Kerk en ander Afrikaanse kerke ' $n$ verlies van openbare invloed ondervind nie, maar ook die Engelse kerke en die Verenigende Gereformeerde Kerk. Alhoewel dié kerke vroeër besondere aansien en invloed in die geledere van die bevrydingsbewegings geniet het, vind ook hulle dit vandag moeilik om invloed op die regering en die openbare lewe uit te oefen. Dit dui daarop dat die vernaamste rede vir 
die afname van die openbare invloed van kerke waarskynlik die skerper skeiding van kerk en staat is wat met die invoering van 'n liberale demokrasie in Suid-Afrika gepaard gegaan het.

\subsection{Openbare sedelikheidswetgewing word geliberaliseer}

Juis vanweë die feit dat die Afrikaanse kerke in die vorige bedeling die simpatieke oor van regeringsleiers gehad het, kon hulle 'n stempel afdruk op wetgewing wat op openbare sedelikheid betrekking gehad het. Hierdie wetgewing het op sy beurt gelei tot die onderskraging van die tradisioneel Gereformeerde sedelikheid wat die Afrikaanse kerke voorgestaan het.

Die groter klem op die vryheid van die individu in die grondwet, en waarskynlik ook die feit dat kerke nog nie in die nuwe bedeling daarin kan slaag om effektiewe nuwe maniere te vind om wetgewing te beïnvloed nie, het teweeggebring dat wetgewing oor dobbelary en lotery, oor sensuur en oor aborsie geliberaliseer is om voorsiening te maak vir 'n groter keusevryheid vir die individu.

\subsection{Die NG Kerk ervaar 'n verlies aan identiteit}

Die vyf dekades sedert die dertigerjare is jare waarin die NG Kerk sterk geassosieer was met die apartheidsbeleid. Dit was egter ook jare waarin dié kerk ' $n$ besonder sterk besef van eie identiteit gehad het. Hierdie sterk identiteitsbelewing is onderskraag deur 'n duidelike en geïntegreerde visie van wat die rol van dié kerk teenoor sy eie lidmate en en in die breëre samelewing moet wees. In 'n reeks verslae, met as hoogtepunt die verslag "Ras, volk en nasie en volkereverhoudinge in die lig van die Skrif" (RVN) van 1974, is hierdie visie teologies uitgebou. RVN bied 'n teologies gesofistikeerde poging om die eie beskouinge van die NG Kerk oor rasseverhoudinge te integreer met tradisioneel Gereformeerde beskouinge oor die kerk en die koninkryk van God.

Die toenemende teologiese kritiek wat teen die eie visie van die NG Kerk uitgespreek is, het gelei tot 'n hersiening van dié visie in "Kerk en Samelewing”. Toe reeds was daar lidmate wat ervaar het dat die aanpassings tot 'n afswakking van die eie identiteit van dié kerk gelei het.

In die nuwe staatkundige bedeling het die vroeëre teologiese visie van die NG Kerk finaal aan legitimiteit verloor. Die NG Kerk het geen ander keuse gehad nie as om fmaal afskeid daarvan te neem nie. Die afskeid het egter ook met die ervaring van 'n verlies aan identiteit gepaard gegaan. Die NG Kerk weet nie meer so duidelik wie hy is, wat sy taak teenoor lidmate en sy roeping in die samelewing is nie. Die feit dat hy hom in 'n totaal nuwe situasie bevind waarin hy nie meer dieselfde invloed op 
die regering en in die openbare lewe het nie, maak dit ook nie makliker om duidelikheid te kry oor die openbare rol wat hy behoort te speel nie.

Die ervaring van identiteitsverlies stel die Ned Geref Kerk, sy gemeentes en lidmate bloot aan invloede van buite: die invloed van modernisering en sekularisasie waarna reeds verwys is, maar ook die invloed van kerke en godsdienstige strominge van nie-Gereformeerde oorsprong. 'n Kerk wat onseker is oor wie hy is en wat sy Godgegewe roeping is, kan homself moeilik verweer teen die aanslag van vreemde invloede van buite.

\subsection{Lidmate word negatief geraak deur regstellende aksie.}

As gevolg van die toepassing van regstellende aksie in die openbare en privaatsektore is daar ' $n$ toenemende aantal lidmate wat skeidingspakkette moet aanvaar of afgedank word, of oorgesien word as dit by bevordering of aanstelling kom. Veral jong blanke mans vind dit moeilik om werk te kry. Van dié jongmense slaag daarin om met behulp van familie en vriende ' $n$ eie onderneming te begin. Daar is egter al hoe meer van hulle wat emigrasie na 'n ander land as 'n uitweg aangryp.

Regstellende aksie het nie net negatiewe geldelike gevolge vir diegene wat daardeur geraak word nie, maar het dikwels ook 'n negatiewe uitwerking op hul werksmotivering en algemene ingesteldheid tot die lewe. Laasgenoemde is soveel erger wanneer regstellende aksie daartoe bydra dat ' $\mathrm{n}$ persoon haar of sy werk verloor, of nie werk kan kry nie 6 . Om werkloos te wees, is 'n besonder traumatiese ervaring wat moeilik verwerk word.

\subsection{Die NG Kerk verswak finansieel}

Dit word algemeen aanvaar dat baie blanke Suid-Afrikaners se finansiële posisie die afgelope paar jaar verswak het. Hierdie verswakking word ook gereflekteer in die finansiële posisie van die Ned Geref Kerk. Dit blyk onder andere uit die talle vakante predikantsposte wat nie gevul word nie of afgeskaf word, proponente wat slegs tydelik en deeltyds aangestel word en gemeentes wat om finansiële redes van hul predikante beskikbaar stel vir beroeping of met ander gemeentes saamsmelt .

Die oorgang na 'n nuwe bedeling alleen kan nie vir die verswakking verantwoordelik gehou word nie. Die verswakking van 'n groot gedeelte van die blankes se finansiële posisie het reeds teen die tweede helfte van die sewentigerjare 'n aanvang geneem. Faktore soos hoë inflasie, devaluasie van die rand en gebrekkige ekonomiese groei het toe reeds 'n rol gespeel. Groeiende onbetrokkenheid by lidmate wat wel in staat is om 'n behoorlike kerklike bydrae te maak, speel ook 'n rol. 
Dat die oorgang wel bydra tot die verswakking van die finansiële posisie van 'n gedeelte van die NG Kerk se lidmate, kan egter nie ontken word nie. Regstellende aksie, asook hoër belastings, die opheffing van landbousubsidies, groter uitgawes ten opsigte van onderwys en opleiding en minder studiebeurse bring teweeg dat baie lidmate minder besteebare fondse het. Dit verplig hulle om strenger tussen noodsaaklike en nienoodsaaklike uitgawes te onderskei en op laasgenoemde te besnoei. Kerkbydraes word dikwels as nie-noodsaaklike uitgawes beskou.

\subsection{Die NG Kerk en sy lidmate word uitgedaag om in die reine te kom met die verlede}

'n Aantal lidmate moes die afgelope twee jaar voor die Waarheids- en Versoeningskommissie of in howe verskyn oor vermeende menseregteskendings in die verlede. Die NG Kerk is egter self deur die WVK versoek om ' $n$ voorlegging te doen. Dié versoek is aanvanklik om verskeie redes afgewys. Die NG Kerk het verkies om 'n publikasie "Reis met apartheid" te laat verskyn waarin die kerk se rol ten aansien van apartheid kortliks uiteengesit word?. Later was die NG Kerk wel bereid om getuienis voor die WVK af te lê, maar slegs oor sy versoeningsrol in die samelewing.

In die nuwe bedeling word die NG Kerk en sy lidmate uitgedaag om in die reine te kom met hul eie verlede. Vanweë die rol wat ons kerk in die ondersteuning van apartheid gespeel het, ervaar hy beslis in die nuwe bedeling 'n geloofwaardigheidsprobleem. Hierdie geloofwaardigheidsprobleem sal eers oorkom word as diegene wat onder apartheid gely het, afdoende daarvan oortuig word dat die NG Kerk berou het oor die rol wat hy ten aansien van apartheid gespeel het, dat hy alle rassevooroordeel in eie geledere oorwin het en dat hy 'n versoenende en dienende rol in die samelewing speel.

\subsection{Die ekumeniese isolasie van die NG Kerk deurbreek}

Vanweë die feit dat die NG Kerk in die vorige politieke bedeling geassosieer was met die apartheidsbeleid en die Nasionale Party-regering, het hy mettertyd ekumenies geïsoleerd geraak. Een van die onmiskenbaar positiewe gevolge van die nuwe politieke bedeling is dat ekumeniese verhoudinge met binnelandse en buitelandse kerke veel meer ontspanne geword het. Die leiers, teoloë en predikante van ander kerke in die buite- en binneland reik op veel groter skaal en veel meer onbevange uit na hul eweknieë in die NG Kerk. Waar lidmaatskap van sekere ekumeniese organisasies in die buite- en binneland vroeër vir die NG Kerk gesluit was, word die weg tot volle lidmaatskap van dié organisasies nou gebaan. Dit 
bied aan die NG Kerk nuwe en vroeēr ongekende moontlikhede tot ekumeniese samewerking. Die uitbouing van ekumeniese verhoudinge in die toekoms hang egter in 'n belangrike mate af van die verhouding tussen die NG Kerk en die Verenigende Gereformeerde Kerk. Indien die onderhandelinge oor kerkvereniging misluk en die vertrouensverhouding tussen die NG Kerk en die VGK verbreek word, sal ekumeniese verhoudinge met ander kerke ernstig gestrem word.

\section{DIE REAKSIE VAN LIDMATE}

\subsection{Die oorwegend negatiewe ingesteldheid van baie lidmate teenoor die nuwe Suid-Afrika}

Lidmate openbaar uiteenlopende houdings teenoor die nuwe Suid-Afrika. Aan die een uiterste van die spektrum is daar lidmate wat 'n ongekwalifiseerd positiewe houding het. Hulle wys op die beëindiging van die militêre stryd en sanksies, die meer ontspanne verhouding tussen bevolkingsgroepe, die verbetering van die ekonomiese situasie en die deurbreking van die kulturele isolasie. Aan die ander uiterste van die spektrum is daar lidmate wat 'n ongekwalifiseerd negatiewe houding het. Hulle wys op die negatiewe gevolge van regstellende aksie vir veral wit Afrikaners, die afskaling van die rol van Afrikaans in die openbare lewe, die bedreiging van standaarde deur die ingrypende transformasie van die onderwys, asook toenemende korrupsie en misdaad in die samelewing. Die meerderheid lidmate pas waarskynlik êrens tussen hierdie twee uiterstes in. Hulle voel positief oor sekere ontwikkelinge, maar negatief oor andere. Waarskynlik die meerderheid van die lidmate het op hierdie tydstip 'n oorwegend negatiewe houding teenoor die nuwe Suid-Afrika. Hierdie instelling gaan dikwels gepaard met 'n negatiewe siening van die toekoms van ons land. Daar is baie lidmate wat vrees dat daar vir hul persoonlik en vir hul kinders nie 'n plek in die Suid-Afrika van die toekoms sal wees nie.

\subsection{Onttrekking aan die openbare lewe}

Mense wat negatief oordeel oor die politieke, ekonomiese en sosiale ontwikkelinge in die samelewing en ook die gevoel het dat hulle in elk geval niks daaraan kan doen nie, is geneig om hulle aan die openbare lewe te onttrek. Dit is ' $n$ verskynsel wat vandag by baie lidmate aangetref word. Van hulle verval in 'n soort geestelike emigrasies. Hulle neem volkome afstand van wat in die land gebeur en trek hulle terug in 'n eie private sfeer van suiwer persoonlike verhoudings, belangstellings en godsdiensbeoefening. Nog ander maak hulle ook letterlik los van hierdie land en sy mense 
deur na 'n ander land te emigreer. Waar die meeste lidmate minder as tien jaar gelede nog sterk afwysend teenoor emigrasie gestaan het, is daar nou verbasend baie van hulle wat emigreer of graag wil emigreer.

\subsection{Beklemtoning van die regte van die eie kultuurgroep}

Daar is 'n groep lidmate wat wel bereid is om betrokke te raak by die openbare lewe. Die doel van hul betrokkenheid is primêr om te stry vir die regte van die Afrikaner wat na hul mening in die huidige Suid-Afrika misken word. Hulle stry onder andere vir die behoud van Afrikaanse skole en vir die erkenning van Afrikaans in die massamedia.

Oor die strategie wat gevolg moet word om die regte van Afrikaners te handhaaf, loop die menings van hierdie lidmate uiteen. Sommige is van mening dat dié regte slegs gehandhaaf kan word in ' $n$ afsonderlike volkstaat vir die Afrikaner. Ander meen dat 'n volkstaat nie haalbaar is nie, en dat die stryd vir Afrikaans binne die nuwe Suid-Afrika en in vennootskap met ander Afrikaanssprekendes besleg moet word. Menings loop ook uiteen oor die rol wat die kerk in die bevordering van die Afrikaner se saak behoort te speel. Daar is lidmate wat meen dat die NG Kerk 'n aktiewe rol in die taal- en skoolstryd behoort te speel, terwyl ander meen dat die verlede leer dat die kerk dié stryd liefs aan die lidmate self moet oorlaat.

\subsection{Swakker sosiale binding aan die Ned Geref Kerk}

Die feit dat die NG Kerk en ander Afrikaanse kerke nie meer dieselfde openbare invloed en sosiale status het nie, lidmaatskap nie meer soveel sosiale voordeel inhou nie en predikante nie meer dieselfde gesag in die openbare lewe het nie, bring teweeg dat veral minder meelewende lidmate 'n swakker sosiale binding aan die kerke ervaar as voorheen. Hulle voel hulle nie meer in dieselfde mate verplig om eredienste by te woon, gereelde geldelike bydraes te gee of lidmate van die Afrikaanse kerke te bly nie. Die resultaat is nog groter onbetrokkenheid by gemeentelike aktiwiteite en ' $n$ toename in die aantal lidmate wat bereid is om te bedank en by ander kerke aan te sluit.

'n Bykomende faktor is die feit dat lidmate nie slegs ervaar dat die NG Kerk en ander Afrikaanse kerke minder erkenning in die samelewing geniet nie, maar dat daar 'n negatiewe ingesteldheid teenoor dié kerke bestaan vanweë hul ondersteuning van die apartheidsbeleid. Dit is veral vir jong lidmate wat self nie voorstanders van apartheid was nie, moeilik om die verlede van die Afrikaanse kerke en die negatiewe openbare mening oor dié verlede te verwerk. 


\subsection{Groter morele en leerstellige onsekerheid by lidmate}

Die verwarrende invloed van die ingrypende liberalisering van openbare sedelikheidswetgewing op lidmate moenie onderskat word nie. Baie lidmate het hulle tot dusver maar min verantwoord ten opsigte van hul afwysing van dobbelary, pornografie, dwelmgebruik, aborsie, ensovoorts. Hul morele standpuntinname was grootliks gebaseer op die feit dat die wet dié dinge verbied het en dat die kerk daartéén was. In 'n nuwe situasie waarin hulle gekonfronteer word met praktyke wat vroeër verbied is, asook met allerlei argumente om dié praktyke te regverdig, ervaar lidmate wat nie geleer het om hulleself behoorlik te verantwoord nie, beslis groter morele onsekerheid.

Tot die groter morele onsekerheid dra ook die groter geneigdheid by om morele kwessies aan die hand van die nuwe grondwet en die handves van menseregte wat daarin vervat is, te besleg. Wat in die grondwet voorop staan, is die vryheid van die individu om te dink, sê en te doen wat hy/sy wil. Dit wat die individu doen of sê, mag slegs beperk word in soverre dit skade aan medemense kan berokken. Dit is duidelik dat op so 'n grondslag 'n besonder wye spektrum van gedrag wetlik en ook moreel geoorloof kan word. Dat lidmate wat nie geleer het om hul standpuntinname vir 'n tradisioneel Christelike moraal te verantwoord nie, grondig verwar kan word deur 'n moraal gebaseer op die vryheid van die individu, ly geen twyfel nie.

Daarby kom nog die feit dat lidmate veel meer as voorheen blootgestel word aan positiewe voorstellings van ander godsdienste in die massamedia. Lidmate wat grootgeword het met oorwegend negatiewe voorstellings van ander godsdienste, word toenemend uitgedaag om die leerstellige en morele standpunte van hul eie konfessie te verantwoord. Dié wat nie daartoe in staat is nie, ervaar die groter blootstelling aan die standpunte en praktyke van ander godsdienste as 'n aanvegting.

\subsection{Groter worsteling oor eie Gereformeerde identiteit}

Dit blyk nou reeds dat die groter morele en leerstellige onsekerheid by sommige lidmate lei tot 'n worsteling oor hul eie identiteit as Gereformeerdes of selfs as Christene. Die Gereformeerde identiteit van lidmate van die NG Kerk was in die verlede in 'n belangrike mate verknoop met heel spesifieke leerstellige en morele oortuigings en aanbiddingspraktyke. Leerstellige oortuigings soos dat Christus die enigste Verlosser is en die Bybel die enigste en betroubare Woord van God, asook die morele afwysing van handeldryf en sport op Sondag, voorhuwelikse seks, egskeiding, naaktheid in die media, dobbelary en aborsie, asook die beoefening van 'n 
sobere spiritualiteit in die erediens was almal ankerpunte van die Gereformeerde identiteit van lidmate. Namate al die oortuigings en praktyke wat die onderskeibare identiteit van Ned Geref Kerklidmate kenmerk, nie slegs deur buitestaanders nie, maar ook al meer deur lidmate en predikante van die NG Kerk self bevraagteken word, sal die ervaring van identiteitsverlies by lidmate waarskynlik al hoe sterker word.

Daar is minstens twee gevare verbonde aan sodanige ervaring van identiteitsverlies. Die eerste gevaar is dat lidmate begin twyfel oor dit wat hulle van nie-Gereformeerdes of selfs nie-Christene onderskei. Ook al lei dit nie daartoe dat hulle die Christelike geloof opsê nie, kan dit daartoe lei dat hulle van kerkgenootskap verwissel of kerklik volledig onbetrokke raak. ' $n$ Tweede gevaar is fundamentalisme. Mense hou nie daarvan om onsekerheid te ervaar nie, veral nie as dit om godsdienstige sake gaan nie. Een manier om dié onsekerheid te besweer, is om terug te gryp na tradisionele oortuigings en praktyke en eenvoudig blindweg, sonder enige poging tot verantwoording, daaraan vas te hou. 'n Kenmerk van sulke fundamentalistiese lidmate is dat hulle ongenuanseerde en eenduidige standpunte inneem en onverdraagsaam is teenoor almal met standpunte wat enigsins van hul eie afwyk.

\subsection{Die verskeidenheid onder lidmate neem toe}

Namate die openbare invloed van die Gereformeerde leer en sedes afneem en lidmate meer blootgestel word aan die invloede van modernisering en ander konfessies, godsdienste en lewensbeskouinge, kan verwag word dat ook die verskeidenheid leerstellige en morele oortuiginge, asook die verskeidenheid in geloofsbelewing, onder lidmate sal toeneem. Nou reeds neem kerklike en openbare debatte oor die voorsienigheid van God, die Godheid van Christus, Christus as enigste Verlosser, Skrifberoep in die dogmatiek en etiek, saamwonery, homoseksualiteit, die verhouding van man en vrou in die huwelik ${ }^{9}$ en in die samelewing, aborsie, genadedood en sang en musiek in die erediens toe. Hoogs waarskynlik sal lidmate steeds meer 'n verskeidenheid standpunte oor al dié kwessies hê en hulle nie so maklik neerlê by amptelike standpunte van die kerk nie. Wat reeds duidelik waargeneem kan word, is dat daar opvallende verskille tussen bepaalde gemeentes van die NG Kerk is wat die inkleding van die erediens en spiritualiteitsbelewing betref. 
5.1 Die NG Kerk moet duidelikheid kry oor wat dit beteken om kerk van Christus in die nuwe Suid-Afrika te wees

Vanweë die ingrypende verskuiwinge wat in die Suid-Afrikaanse samelewing oor die afgelope paar jaar plaasgevind het, ervaar die NG Kerk (en sy lidmate) 'n sekere verlies aan identiteit. 'n Kerk wat onseker raak oor wie hy is, is 'n kerk wat ook onseker raak oor wat sy roeping in die samelewing is. Om duidelikheid te kry oor sy roeping in die nuwe SuidAfrika, sal die NG Kerk dus duidelikheid moet kry oor wie hy is en wil wees.

In sy soeke na identiteit, kom die NG Kerk voor verskillende versoekinge te staan, waaronder:

* Die versoeking om hom te vereenselwig met die negatiewe en afsydige houding van baie lidmate teenoor die nuwe Suid-Afrika en hom te weerhou van enige sosiale betrokkenheid.

* Die versoeking om opnuut die saak van die Afrikanervolk sy saak te makk en voor alles om te sien na die belange van dié volk.

Die Skrif en ook die Gereformeerde belydenisskrifte leer dat die kerk die uitsluitlike taak het om God en sy koninkryk te dien. Dit beteken onder andere dat die kerk en sy lidmate in die eerste plek lojaliteit aan God en sy koninkryk verskuldig is. Die band tussen die burgers van God se koninkryk, tussen die volksgenote van die geloof, is eweneens 'n band wat sterker behoort te wees as enige ander band wat mense aan mekaar bind. Meer nog: die samestelling van die kerk as volk van God word uitsluitlik bepaal deur geloof in Jesus Christus. Niemand word uitgesluit op grond van faktore soos ras, volk, klas of geslag nie. In hul optrede teenoor mekaar mag lidmate van die kerk ook nie op grond van sulke faktore teen mekaar diskrimineer nie ${ }^{10}$.

Dit is die roeping van die kerk om die voorhoede van die koninkryk van God te wees. In hul optrede teenoor mekaar moet lidmate 'n toonbeeld bied van die nuwe orde wat in dié koninkryk heers. Hulle moet mekaar liefhe soos hulleself, mekaar bystaan in nood en steeds bereid wees tot versoening as onmin tussen hulle ontstaan. Hul diens aan God en sy koninkryk gaan egter nie op in onderlinge diens aan mekaar nie. Die koninkryk van God is 'n omvattende ryk wat, onder andere, betrekking het 
op al die verhoudinge waarin die lidmate staan en op al die samelewingsverbande waarin hulle optree ${ }^{11}$. Die institusionele kerk kan dié omvattende koninkryksdiens nie alleen lewer nie. Sy taak is voor alles om lidmate toe te rus om hierdie diens op alle lewensterreine te kan lewer. Dié toerusting is egter alleen effektief as die institusionele kerk self ' $n$ inspirerende voorbeeld van 'n eensgesinde en liefdevolle gemeenskap bied, as hy projekte loods wat sonder onderskeid die nood van diegene wat geen hulp het nie lenig en as hy die lig van God se Woord laat val op samelewingsontwikkelinge.

In die lig hiervan is dit duidelik dat die NG Kerk nie mag toegee aan die versoeking om die saak van die Afrikanervolk sy eie te maak, of aan die versoeking om sosiaal onbetrokke te bly nie. Ongetwyfeld mag die NG Kerk in bewoënheid die nood van sy Afrikanerlidmate in die nuwe SuidAfrika probeer lenig. Hy mag egter nie slegs die nood van Afrikaners raaksien en die nood - selfs groter nood - van soveel ander mense in die samelewing ignoreer nie. Net so min mag hy op 'n onkritiese wyse die politieke sentimente en standpunte van Afrikaners oorneem en ondersteun. Hy het eerder die verantwoordelikheid om dié sentimente en standpunte aan die kritiese lig van Gods Woord te onderwerp.

Dat daar bepaalde faktore is wat dit vir die NG Kerk moeilik maak om in die huidige Suid-Afrika volledig kerk van Christus te wees en omvattende koninkryksdiens te lewer, kan kwalik ontken word. Een van dié faktore is die feit dat die gemeentes van die NG Kerk - op enkele uitsonderings na - feitlik uitsluitlik lidmate uit Afrikanergeledere het. Dit bring teweeg dat die NG Kerk en sy lidmate nie in eie geledere blootgestel word aan die nood van ander bevolkingsgroepe nie. Gemeentes is dikwels geneig om oorwegend aandag te gee aan die leniging van die nood van Afrikanerlidmate wat voorhande is. Dit bring ook teweeg dat die NG Kerk en sy lidmate nie in eie geledere blootgestel word aan die standpunte van Christene uit ander bevolkingsgroepe wat as 'n korreksie kan dien vir eensydige standpunte nie.

'n Tweede faktor is die geloofwaardigheidsprobleem van die NG Kerk waarna reeds verwys is. Daar is nog baie mense uit die geledere van ander bevolkingsgroepe wat die NG Kerk in die inisiatiewe wat hy onderneem, wantrou. Daarom kry hy ook nie altyd die samewerking van kerke en gemeentes wat dié bevolkingsgroepe bedien as hy wel inisiatiewe onderneem om die nood van mense oor die kleurgrens te lenig nie.

Hierdie twee belemmerende faktore sal waarskynlik meer effektief gehanteer kan word as die familie van Ned Geref Kerke verenig. Dan sal blanke lidmate nader aan die nood van mense uit ander bevolkingsgroepe 
kom en sal hul eensydige standpunte en houdings sterk uitgedaag word. Dan sal die NG Kerk ook bevry kan word van die las van ongeloofwaardigheid, omdat kerkvereniging vir baie die deurslaggewende toets is wat sal bepaal of hy gereed is om omvattende koninkrykdiens in die nuwe SuidAfrika te lewer.

\subsection{Die NG Kerk moet sy lidmate inspireer om hul Christelike roeping in die nuwe Suid-Afrika na te kom}

As kerk van Christus moet die NG Kerk bereid wees om omvattende koninkryksdiens in die nuwe Suid-Afrika te lewer. Die NG Kerk kan dit egter alleen doen as sy lidmate bereid is om in al die verhoudinge waarin hulle staan en al die samelewingsverbande waarin hulle optree koninkryksdiens te lewer.

Lidmate het die roeping om daar waar God hulle plaas, te doen wat God van hulle verwag ${ }^{12}$. Wat dit beteken, kan aan die hand van die werksituasie van lidmate geïllustreer word. Dit beteken dat lidmate die geleenthede wat hul werk hul bied om getuienis van hul geloof in Christus af te lê, moet benut. Die geleenthede wat hul werk hul bied om medemense in nood te help, behoort aangegryp te word. Hulle behoort ook daarna te strewe om in die uitvoering van hul werk steeds getrou te bly aan die wet van God. Dit beteken egter ook dat hulle doodeenvoudig sal probeer om elke aspek van hul werk so goed hulle kan, te verrig. Reeds deur dit te doen, dra hulle by tot die goeie funksionering van die samelewing én word die koninkryk van God gedien.

Die oorwegend negatiewe ingesteldheid wat baie lidmate teenoor die nuwe Suid-Afrika en ook die toekoms van ons land het, maak dit vir hulle bykans onmoontlik om hul Christelike roeping na te kom en 'n konstruktiewe rol in die nuwe Suid-Afrika te speel. Iemand met so 'n ingesteldheid is eerder geneig om op die kantlyn te staan en kyk hoe alles ten gronde gaan. Sommige is selfs bereid om die nuwe bedeling aktief teen te werk deur in die staatsdiens voete te sleep of die uitvoering van besluite teen te werk of deur belasting te ontduik.

Die NG Kerk het die verantwoordelikheid om lidmate met so 'n negatiewe ingesteldheid pastoraal te begelei. Die belangrike vraag is egter: Hoe geskied hierdie pastorale begeleiding? Word die negatiewe ingesteldheid onkrities aanvaar en bevestig of word eerder profetiese kritiek uitgespreek teen dit wat nie Christelik verantwoord kan word nie? Word hulle vertroos deur 'n wêreldvreemde boodskap van "hier benede is dit nie, maar in die hiernamaals is dit wel", of word hulle ook uitgedaag om die beperkte ruimte vir inisiatief wat hulle nog het aan te gryp en van hierdie land ' $n$ beter plek te maak? 
Ten grondslag van die negatiewe ingesteldheid lê dikwels oortuigings wat nie Christelik verantwoord kan word nie. Dit berus by sommige op die oortuiging dat dit in die samelewing onafwendbaar slegter sal gaan. Afgesien daarvan dat die geskiedenis leer dat ons nie op grond van wat vandag gebeur, met sekerheid kan weet wat môre en oormôre sal gebeur nie, is dit 'n vraag of so 'n aanname nie van 'n gebrek aan geloof in die God wat voorsien, getuig nie. Juis omdat ons as Christene glo dat 'n magtige en goeie God in beheer van die geskiedenis is, mag ons nooit moed opgee oor die toekoms van ons land nie. By ander berus die negatiewe ingesteldheid op ' $n$ onderliggende negatiewe beoordeling van die magsoordrag van 1994. Hulle het nog nie vrede gemaak met die politieke magsoordrag of die konsekwensies wat dit vir hulle inhou nie. Dit is so dat ons beslis nie alles wat ná April 1994 in ons land gebeur het, as moreel reg hoef te aanvaar nie. As Christene sal ons egter moet aanvaar dat die oordrag van politieke mag aan 'n demokraties verkose regering moreel verkieslik is bo die voortgesette politieke oorheersing van 'n meerderheid Suid-Afrikaners deur 'n minderheid.

Daar is nog 'n rede waarom profetiese kritiek teen die negatiewe ingesteldheid van lidmate gelewer moet word. Lidmate met so 'n ingesteldheid sien dikwels nie raak dat dié ingesteldheid en die negatiewe optrede wat daaruit voortspruit juis bydra tot die negatiewe ontwikkelinge in die samelewing wat hulle so beangs maak nie. 'n Oormatig negatiewe houding van blanke lidmate teenoor alles wat in die nuwe Suid-Afrika gebeur, ry versoening met swartmense wat die vorige bedeling as veel erger ervaar het beslis in die wiele. Dit is so dat lidmate in die staatsdiens hulle soms in 'n onhoudbare situasie bevind en nie anders kan as om te bedank nie. Tog bly dit 'n onmisbare feit: Deur voete te sleep in die staatsdiens of ongevraagd uit die staatsdiens te bedank, terwyl jou kundigheid daar dringend benodig word, dra jy by tot die oneffektiwiteit van die staatsdiens en versterk jy die kans dat die negatiewe verwagtinge vir die toekoms bewaarheid sal word.

Spesiale melding moet hier gemaak word van die geneigdheid van steeds meer lidmate om te emigreer. Dit is ongetwyfeld so dat baie mense emigreer om begryplike en aanvaarbare redes. Dit is ook so dat die besluit om te emigreer ' $n$ intens persoonlike besluit is wat geskied op grond van motiewe en oorwegings wat moeilik deur buitestaanders gepeil en beoordeel kan word. Daarom sou 'n algemeen negatiewe oordeel oor mense wat emigreer nie verantwoord wees nie.

Dit sluit egter nie 'n gesprek uit oor die moontlike rol wat onaanvaarbare negatiewe motiewe en sieninge in die besluite van lidmate 
om te emigreer, speel nie. Lidmate wat dit oorweeg om te emigreer, behoort hul eie motiewe en sieninge krities in oënskou te neem. Hulle behoort ook die negatiewe gevolge van 'n grootskaalse verlies aan kundigheid deur emigrasie vir Suid-Afrika in berekening te bring.

Die NG Kerk behoort lidmate te vra om slegs te emigreer as hulle daarvan oortuig is dat dit die wil van die Here is. By die redes wat reeds genoem is, kom die oortuiging wat nog altyd sterk in Gereformeerde kringe geleef het dat gelowiges juis daar waar God hul plaas, hul roeping moet vervul. Op grond van hul geloof in God se voorsienigheid aanvaar Gereformeerdes nie dat dit toevallig of om't ewe is dat hulle in ' $n$ bepaalde land op ' $n$ bepaalde tydstip van die geskiedenis woonagtig is nie. Hulle glo dat God hul daar plaas met 'n bepaalde roeping en dat hulle daarom erns daarmee moet maak om vas te stel wat dié roeping is. Hulle sal daarom ook nie alte gou padgee uit moeilike omstandighede nie, omdat dit kan beteken dat hulle hul roeping versaak. Eers as hulle daarvan oortuig raak dat God vir hulle elders ' $n$ ander roeping het, sal hulle emigreer.

Die NG Kerk moet by hierdie Gereformeerde oortuiging aansluiting vind, nie net om profetiese kritiek teen die negatiewe ingesteldheid en optrede van lidmate te lewer nie, maar ook om hulle te inspireer om 'n konstruktiewe rol in die nuwe Suid-Afrika te speel. Die feit dat die NG Kerk in die vorige bedeling soms ' $n$ inhoud aan die Godgegewe roeping van sy lidmate gegee het wat hul bevoorregte en leidinggewende posisie in die samelewing regverdig het, mag hom nie daarvan weerhou om inhoud te gee aan die Godgegewe roeping van sy lidmate in die huidige bedeling nie. Sou dit nie wees dat lidmate in die nuwe Suid-Afrika die roeping het om in diensbaarheid 'n konstruktiewe rol in die hantering van die groot uitdagings wat ons samelewing bied, te speel nie? Ten spyte van die feit dat die ruimte vir inisiatief van lidmate minder is as tevore, beskik hulle oor die kundigheid en in baie gevalle ook oor die finansiële middele om 'n belangrike bydrae tot politieke stabiliteit en ekonomiese voorspoed in ons land te lewer. Trouens, juis vanweë die feit dat hulle oor die kundigheid en finansiële middele beskik, lê op hulle as Christene die morele verantwoordelikheid om 'n konstruktiewe rol in die aanpak van die groot uitdagings wat Suid-Afrika bied, te speel.

'n Belangrike les wat almal van ons wat aan die NG Kerk verbonde is uit die Skrif en uit die kerkgeskiedenis kan leer, is dat koninkryksdiens nie slegs uit 'n posisie van mag gelewer kan word nie. Die geskiedenis leer eerder dat kerke en individuele gelowiges in 'n magsposisie dit dikwels moeilik vind om werklik diensbaar te wees. Die rede daarvoor is dat die diens wat Christus van ons verwag 'n gesindheid van ootmoed vra, 'n 
gewilligheid om met die swakstes in die samelewing en hulle nood te identifiseer. Aan so ' $n$ diens is daar nie baie glans, nie baie erkenning verbonde nie.

Dit is 'n vraag of die NG Kerk en sy lidmate in 'n situasie waarin hulle oor minder mag beskik, nie beter in staat sal wees om die soort koninkryksdiens wat God van hulle verwag, te verrig nie. Twee van die grootste probleme in ons samelewing bly nog steeds die verdeeldheid tussen politieke en etniese groepe en die voorkoms van grootskaalse armoede. In die vorige bedeling was die NG Kerk en sy lidmate te veel geassosieer met die Nasionale Party-regering en die apartheidsbeleid om 'n werklik effektiewe bydrae tot die oplossing van dié probleme te lewer. In die nuwe bedeling het hulle die geleentheid om, in samewerking met ander, 'n belangrike bydrae tot die oplossing van dié probleme te lewer. Dan moet die dienskneggestalte van hul Heer, Jesus Christus, egter in hul optrede duidelik sigbaar word.

Beteken dit nou dat die NG Kerk en sy lidmate nie kritiek mag uitspreek teen wat in die nuwe Suid-Afrika gebeur nie? So 'n afleiding sou in stryd wees met die roeping van die kerk om profetiese kritiek uit te spreek teen samelewingsontwikkelinge wat in stryd is met God se Woord. Daar is in die huidige samelewing meerdere ontwikkelinge wat kommer wek en kritiese kommentaar van die kerk verdien. Die toename van korrupsie in die staatsdiens en die oneffektiewe misdaadbestryding van die polisie, howe en korrektiewe dienste, is maar twee voorbeelde. Die NG Kerk moet egter versigtig wees om nie op 'n selektiewe wyse profetiese kritiek teen samelewingsontwikkelinge te lewer nie. Sy kritiek moenie 'n weerspieëling wees van die vrese en belange van sy eie lidmate nie, maar moet eerder die resultaat wees van 'n onbevange ondersoek van samelewingsontwikkelinge in die lig van Gods Woord. Daarby moet in ag geneem word dat die profetiese taak van die kerk nie slegs die verantwoordelikheid inhou om kritiek te lewer nie.' Dit hou ook die verantwoordelikheid in om positiewe kommentaar te lewer op besonder positiewe regeringsinisiatiewe en om die regering daarin te ondersteun. Die houding wat die kerk en sy lidmate dus teenoor die regering moet openbaar, is een van kritiese solidariteit.

\subsection{Die NG Kerk moet sy lidmate toerus om diensbaar te wees in die nuwe Suid-Afrika}

Lidmate kan slegs 'n konstruktiewe rol in die nuwe Suid-Afrika speel as hulle toegerus word om dié rol te kan speel. Die toerusting wat nodig is, is egter nie slegs die toerusting met kennis oor en vaardighede in effektiewe 
dienslewering nie. Die nuwe bedeling het die weg oopgemaak vir ontwikkelinge wat onsekerheid by lidmate oor hul eie Christelike (meer spesifiek: Gereformeerde) identiteit veroorsaak en vreemde waardes by hulle vestig. Lidmate sal slegs 'n konstruktiewe rol in die nuwe bedeling kan speel as die toerusting wat die NG Kerk aan hulle bied hul Christelike identiteit en hul vermoë om aan hierdie identiteit in alle lewensituasies gestalte te gee, versterk.

Die toerusting van lidmate tot diensbaarheid in die nuwe SuidAfrika, behoort dus op twee vlakke te geskied:

Lidmate moet gehelp word om vorm te gee aan 'n outentieke, eietydse Christelike lewenstyl. Een van die spanninge waarin hedendaagse Christene hulle bevind vanweë die verselfstandiging van die verskillende instellinge waarby hulle betrokke is, is dat die waardes en lewenstyle wat binne dié instellinge geld, dikwels in stryd met mekaar verkeer. Die waardes en lewenstyl wat Sondag in die kerk voorgehou word, het dikwels min te doen met dit wat weeksdae in die sakewêreld, saans op TV of Saterdag op die sportveld die norm is. Die gevolg is nie net dat lidmate innerlik versplinter voel nie, maar ook ervaar dat die tradisionele Christelike waardes en lewenstyl vir 'n groot deel van hul lewe geen relevansie het nie.

Een van die grootste uitdagings wat op die NG Kerk wag, is om lidmate te help om die spanning tussen 'n Christelike lewenstyl en waardes aan die een kant en 'n moderne, sekulêre lewenstyl en waardes aan die ander kant, in hulle eie lewens te hanteer. Om dit te kan doen sal die NG Kerk opnuut erns moet maak met die Gereformeerde tradisie as bron van voorbeeldige lewenstyle en rolmodelle. Die Gereformeerde tradisie word naamlik gekenmerk deur die strewe om gestalte te gee aan ' $n$ geïntegreerde lewenstyl wat alle lewensterrein oorbrug. Die NG Kerk sal egter daarteen moet waak om op 'n outoritêre wyse 'n eenvormige, eietydse Christelike lewenstyl, gebaseer op hierdie tradisie, aan alle lidmate voor te hou. Die beste sal wees as elke lidmaat vir hom of haar, elke gesin vir hulleself in die lig van wat uit die tradisie aan hulle gebied word, sal uitmaak watter lewenstyl in hulle unieke omstandighede vir hulle as Christene verantwoord is. Daarom kan die kerk lidmate ten beste help om vorm te gee aan 'n outentieke, eietydse Christelike lewenstyl deur: 
- Hulle te leer dat hulleself daarvoor verantwoordelik is om gestalte te gee aan 'n Christelike lewenstyl wat stand hou en kontinuïteit vertoon op alle lewensgebiede waarby hulle betrokke is.

- Hulle toe te rus met die vaardigheid van morele oordeelsvorming. Om lidmate in hierdie vaardigheid in te oefen, sal gemeentes aan hulle geleenthede moet bied waar hulle met mekaar die netelige, aktuele morele kwessies waarmee hulle in die daaglikse lewe gekonfronteer word, kan bespreek.

- Hulle toe te rus met Christelike morele deugde. Dit is opvallend hoe baie skrywers in hierdie tyd waarin dit nie altyd duidelik is wat die regte ding is om te doen nie, opnuut die waarde van die regte karakter, van die regte deugde beklemtoon $^{13}$. Ten diepste word dit wat ons doen, bepaal deur dit wat ons is, deur die karakter waaroor ons beskik. Die afleiding is voor die hand liggend: In tye van morele onsekerheid het mense wat die regte morele deugde aangekweek het 'n voordeel, omdat hulle 'n fyner aanvoeling sal hê van wat die moreel juiste dinge is om te doen.

Om die regte morele deugde by lidmate aan te kweek, is natuurlik nie iets wat oornag kan gebeur by slegs enkele kontakgeleenthede nie. Die totale toerustingsprogram van 'n gemeente moet daarop afgestem wees. Ons sal veral opnuut moet kyk na die toerusting van die jeug: Hoedat die jeugwerk, kategese en veral die geestelike bediening van ouers aan kinders tot Christelike karaktervorming kan bydra.

Lidmate moet toegerus word met kennis oor en vaardighede in effektiewe dienslewering. Die NG Kerk beskik reeds oor 'n aantal toerustingsprogramme vir lidmate. Die nuwe omstandighede in die samelewing stel die NG Kerk en sy lidmate egter voor nuwe uitdagings met betrekking tot dienslewering en die toerusting tot dienslewering.

Dit is nodig dat die NG Kerk duidelikheid sal kry oor watter vorme van diens hy en sy lidmate in die breëre samelewing behoort te 
lewer. Neem ons sowel die nood in die samelewing as die eiesoortige aard van die diens van die kerk in ag, wil dit voorkom of die NG Kerk en sy lidmate geroepe is om op ten minste drie gebiede diens in die breëre samelewing te lewer:

- Die bevordering van versoening in die samelewing. (Dit sluit ook die regstel van die onreg van die verlede, wat versoening in die weg staan, in).

- Die bestryding van die morele krisis in die samelewing wat tot uitdrukking kom in grootskaalse korrupsie, bedrog en geweld.

- Die bestryding van die nood van die swakstes in die samelewing.

Dit sal weinig nut hê as die NG Kerk lidmate slegs toerus met teoretiese kennis oor die beste metodes van dienslewering op hierdie verskillende gebiede. Lidmate moet ook toegerus word met die vaardighede om effektiewe diens te kan lewer. Die beste manier om sulke vaardighede aan te leer, is indiensopleiding. Daarom rus daar ' $n$ besondere verantwoordelikheid op die gemeentes, ringe en sinodes van die NG Kerk om die nodige diensleweringspro-gramme in te stel waarby lidmate kan inskakel. Dit is egter nie nodig om diensleweringsprogramme te ontwikkel as ander gemeentes en kerke reeds daarin geslaag het om sulke programme suksesvol te ontwikkel nie. Samewerking met ander gemeentes en kerke het noodsaaklik geword in ' $n$ tyd waarin die bronne wat kerke tot hul beskikking het vir dienslewering minder word.

\subsection{Die NG Kerk moet op 'n nuwe manier openbare getuienis in die nuwe Suid-Afrika lewer ${ }^{14}$}

In die vorige bedeling het die NG Kerk by uitstek gebruik gemaak van die sogenaamde "koninklike weg" om sy standpunt oor openbare aangeleenthede aan regeringsleiers oor te dra. In plaas daarvan om via die media invloed op die openbare mening en druk op die regering uit te oefen, is die standpunte van die kerk meestal in persoonlike gesprekke aan regeringsleiers oorgedra. Die NG Kerk kon meestal daarop reken dat regeringsleiers aan sy versoeke sou voldoen. Wanneer die NG Kerk wel standpunt in die openbaar ingeneem het, kon hy meestal daarop reken dat die media afdoende dekking aan sy standpunt sou gee en dat sy standpunt by baie mense gesag sou dra. 
In die nuwe bedeling is die "koninklike weg" nie meer die aangewese opsie vir die NG Kerk nie. Nie alleen het die kerk nie meer noue verbintenisse met regeringsleiers nie, maar maak die nuwe demokratiese bedeling ook nie voorsiening vir die bevoorregting deur die regering van een kerk bo ' $n$ ander kerk, of een godsdiens bo 'n ander godsdiens nie. Die NG Kerk kan ook nie daarop reken dat die media vanselfsprekend dekking sal gee aan sy standpunte oor openbare aangeleenthede of dat mense sy standpunte op gesag sal aanvaar nie.

Die NG Kerk sal 'n paar aanpassings moet maak as hy in die nuwe Suid-Afrika effektiewe openbare getuienis wil lewer:

Hy sal daarna moet streef om die optimale binne-kerklike en ekumeniese konsensus oor belangrike openbare kwessies te bereik. Juis omdat die NG Kerk nie meer daarop kan reken dat selfs sy eie lidmate amptelike kerklike standpunte oor openbare aangeleenthede op gesag sal aanvaar nie, is dit nodig dat hy sal probeer om so veel as moontlik van sy lidmate in die bespreking oor die aangeleenthede te betrek. Alhoewel dit soms lank kan neem om binne-kerklike konsensus te bereik, is die voordeel dat lidmate die standpunte wat langs dié weg ingeneem is, hul eie sal maak.

Aangesien die regering in die nuwe bedeling kwalik na die stem van net een kerk sal luister, is dit van groot belang dat ander kerke en ekumeniese organisasies geraadpleeg word voordat die regering met 'n bepaalde standpunt gekonfronteer word. Indien ekumeniese konsensus oor die betrokke openbare kwessie bereik kan word, sal die impak wat die standpunt op die openbare mening en op die regering het soveel groter wees.

Hy sal bereid moet wees om openbare debatte oor openbare kwessies te voer. Aangesien beïnvloeding van die openbare mening van die uiterste belang is as die kerk enigsins ' $n$ impak op die regering en op die formulering van wetgewing wil maak, sal die NG Kerk bereid moet wees om veel meer as voorheen openbare debatte in die media oor belangrike openbare aangeleenthede te inisiëer en te voer. Die kwaliteit van die argumente moet van so 'n hoogstaande gehalte wees dat die media dit nie kan ignoreer nie en dat die openbare mening sterk beïnvloed word. Om soveel as moontlik mense vir ' $n$ bepaalde standpunt oor 'n openbare kwessie te wen, sal die NG Kerk by geleentheid bereid moet wees om argumente te gebruik wat ook deur nie-Christene verstaan en aanvaar kan word. 


\section{SLOTOPMERKING}

In die lig van die intensiteit van die negatiewe ingesteldheid van baie lidmate teenoor die nuwe Suid-Afrika, maar ook die omvang van probleme in die huidige Suid-Afrika, moet in alle eerlikheid gesê word dat die NG Kerk in die uitoefening van sy omvattende Koninkrykstaak voor geweldige uitdagings staan. In so 'n situasie moet die woorde van Reinhold Niebuhr in 'n toespraak aan die eerste algemene vergadering van die Wêreldraad van Kerke in 1948 oor "The Christian witness in the social and national order" ter harte geneem word:

"Perhaps our generation will fail. Perhaps we lack the humility and charity for the task. There are ominous signs of our possible or even probable failure. There is promise of new life for human beings and nations in the gospel, but there is no guarantee of historic success. There is no way of transmitting the Christian gospel into a system of historical optimism. The final victory over humanity's disorder is God's and not ours; but we do have responsibility for proximate victories".

\section{NOTAS:}

1 White Paper on Reconstruction and Development, Cape Town, 15 November 1994, 7 .

2 Vergelyk D E de Villiers, "Liberal anthropology in the South African context", Journal of Theology for Southern Africa 76 (1991), 15-24 en L D Hulley, "Some human values in society - From a liberal perspective", Journal of Theology for Southern Africa 76 (1991), 25-31 vir 'n bespreking van die invloed van liberale waardes in die Suid-Afrikaanse samelewing in die verlede.

3 Die redes vir die instelling van die WVK en die reaksie daarop deur verskillende bevolkingsgroepe in Suid-Afrika word onder andere bespreek in die bundel: $\mathbf{H}$ R Botman en $\mathbf{R} M$ Petersen (Eds), To remember and heal. Theological and psychological reflections on truth and reconciliation, Cape Town 1996 en A Krog, Country of my skull, Johannesburg 1998.

4 Vergelyk W C Esterhuyse, "Die baie gesigte van korrupsie”, Beeld, 10 Maart 1999, vir 'n goeie oorsig van die verskillende vorme van korrupsie in SuidAfrika.

5 Dié definisie is van J A van der Ven, Ecclesiologie in context, Kampen 1993, 18. Van der Ven bied ' $n$ indringende bespreking van modernisering as konteks van die kerk (17-31).

6 Die verslag "Regstellende aksie" wat deur die Sinodale Kommissie vir Leer en Aktuele Sake aan die Noord-Transvaalse Sinode van die NG Kerk in September 
1997 voorgelê is, bied na my mening nuttige riglyne om te help onderskei tussen verantwoorde en onverantwoorde regstellende aksie (vgl Agenda, 57-58). Die volle titel is: Die verhaal van die NG Kerk se reis met apartheid, 19671994. 'n Getuienis en 'n belydenis, Wellington 1997.

8 Volgens J Moltmann, Man. Christian anthropology in the conflicts of the present, Philadelphia 1974, 37-41, word "innerlike emigrasie" gemotiveer deur passiewe opposisie teen onpopulêre of afkeurenswaardige ontwikkelinge in die wêreld daarbuite. Met die hulp van 'n private kring, 'n eiland van innerlike emigrasie en ironiese opmerkings op die situasie verkry sulke mense 'n staanplek buite die openbare "ellende" en skep hulle vir hulself afstand teenoor die alledaagse lewe.

9 Vergelyk die onlangse openbare debat oor die voorstel van Christina Landman in ' $n$ rubriek in Beeld dat poligamie in Suid-Afrika ook vir ander groepe as swartmentse oorweeg moet word.

10 Vergelyk Kerk en Samelewing, Bloemfontein 1986. In paragraaf 62 word na aanleiding van die belydenis dat die kerk 'n geloofs-, belydenis- en aanbiddingsgemeenskap is, gesề "dat geloof in die Drieënige God en sy openbaring in die Skrif die enigste voorwaarde vir lidmaatskap van die kerk van Jesus Christus is".

11 Vergelyk vir 'n bespreking van spesifiek die omvattende vredestaak van die kerk, D E de Villiers, "Die evangelie van vrede en vrede in Suid-Afrika", in: C J Wethmar en C J A Vos (Reds), ' $n$ Woord op sy tyd. 'n Teologiese feesbundel aangebied aan prof Johan Heyns ter herdenking van sy sesigste verjaarsdag, Pretoria 1988, 9-22 (veral 14-16).

12 Vergelyk D J Smit se referaat "Morality and individual responsibility", by die Moraliteitskonferensie, Windhoek, 28 en 29 Oktober 1993, 13: "This is certainly the moral responsibility of Christians as well: Not to withdraw into our private spheres, but to take our divine calling seriously, to live in the concrete world, in the particular society, where God has placed us and where God is calling us. To live there truthfully, with integrity, according to the Christian story and in the Christian community of character. To involve ourselves in the institutions through which we can serve the people whom God has entrusted to us as fellow human brings. To contribute through those institutions to a human future for the children, our children, all children. To remember that, through our ideas and words, our actions and omissions, we do make a differencen.

13 Vergelyk onder andere N Richardson, "Ethics of character and community", in: C Villa-Vicencio en J de Gruchy (Eds), Doing ethics in context. South African perspectives, Cape Town 1994, 89-101 en R Vosloo, "Back to virtue? Some remarks on the reappraisal of virtue in ethics", Scriptura 62/3 (1997), 191-210.

14 Vergelyk D E de Villiers en D J Smit, "'Met watter gesag sê u hierdie dinge?' Opmerkings oor kerklike dokumente oor die openbare lewe", Sknf en Kerk 16/1 (1995), 39-56, vir 'n uitvoerige bespreking van die aanpassings wat die kerk moet maak ten aansien van sy uitsprake oor die openbare lewe in hedendaagse demokratiese samelewings. 